KRZYSZTOF WASILEWSKI

Wydział Humanistyczny

Politechnika Koszalińska

ORCID: 0000-0002-5378-2822

krzysztof.wasilewski@tu.koszalin.pl

\title{
Miasta i paradyplomacja pamięci
}

Międzynarodowy wymiar lokalnych polityk historycznych

\section{Cities and memory paradiplomacy}

The international dimension of local politics of memory

Słowa kluczowe: polityka historyczna, paradyplomacja, miasta, samorządy, stosunki międzynarodowe
Keywords:

memory politics, paradiplomacy, cities, local governments, international relations 
Cities and memory paradiplomacy. The international dimension of local politics of memory

The role of cities in international relations is systematically growing. Many contemporary global initiatives in the field of environmental protection, combating social inequalities or illegal immigration originate from the foreign activity of local governments. Cities seem to be more willing to build their international potential through so-called memory diplomacy. The past, or in fact a top-down form of its commemoration or forgetting, becomes one of the main categories of foreign policy. By using various tools of implementing memory policy, such as the construction of public space or supporting activities of memory institutions, local governments create the desired image in the international arena and, consequently, strengthen their own economic and political potential. 


\section{Wstęp}

Dola miast w stosunkach międzynarodowych systematycznie wzrasta. ACzęść politologów dowodzi wręcz, że XXI w. to wiek dominacji miast, zarówno w odniesieniu do ich pozycji wewnętrznej, tj. w relacjach z władzami centralnymi, jak i w otoczeniu zewnętrznym ${ }^{1}$. Wiele współczesnych inicjatyw globalnych z zakresu ochrony środowiska, walki z nierównościami społecznymi czy nielegalną imigracją bierze swój początek w aktywności zagranicznej samorządów. Chociaż zatem jest to nadal domena największych metropolii, ich śladem zaczynają podążać - w miarę swoich możliwości - także mniejsze ośrodki ${ }^{2}$. Co więcej, obok włączania się w działalność humanitarną lub klimatyczną coraz chętniej miasta budują swój międzynarodowy potencjał poprzez tzw. dyplomację pamięci. Przeszłość, a w zasadzie odgórnie usankcjonowana forma jej upamiętnienia lub zapomnienia, staje się bowiem jedną z nadrzędnych kategorii polityki zagranicznej. Z jednej strony może być ona zarzewiem konfliktów dyplomatycznych, jak chociażby w przypadku sporów polsko-rosyjskich o genezę drugiej wojny światowej ${ }^{3}$. Z drugiej zaś równie często jest ona stosowana w celu kreowania pozytywnego wizerunku na arenie międzynarodowej. Wykorzystując różne narzędzia realizowania polityki historycznej, jak np. zagospodarowanie przestrzeni publicznej czy wspieranie działalności instytucji pamięci, samorządy tworzą pożądany wizerunek na arenie międzynarodowej, a w konsekwencji wzmacniają własny potencjał gospodarczy i polityczny ${ }^{4}$. Tak sformułowana teza stanowi kanwę niniejszego artykułu, którego celem jest analiza zagranicznej polityki historycznej miast z uwzględnieniem polskich i zagranicznych samorządów. Sam artykuł ma charakter przeglądowy, opiera się przede wszystkim na literaturze przedmiotu oraz już opublikowanych badaniach - przeprowadzonych zarówno przez autora, jak i przez

1 D. Held, A. McGrew, "The End of the Old Order?”. Globalization and the prospects for world order, „Review of International Studies” 2001, vol. 24, no. 3, s. 219-245.

2 Por. np. S. Faliński, Wspótpraca międzynarodowa miasta na prawach powiatu. Przykład Płocka, „Studia z Polityki Publicznej” 2019, nr 3(23), s. 109-125.

3 Por. A. Brzeziecki, K. Markowski, Wszystkie nasze spory o pamięć, „Znak” 2020, nr 5 , s. $38-43$.

4 M. Raś, Aktywność międzynarodowa regionów (paradyplomacja) w ujęciu teoretycznym, „Stosunki Międzynarodowe” 2016, nr 3, s. 191-214. 
innych badaczy. Tym samym stanowi zatem wprowadzenie do tematyki paradyplomacji pamięci oraz wskazuje główne kierunki badawcze. Wybrane i opisane przykłady zostały dobrane $\mathrm{w}$ ten sposób, aby zilustrować cele i narzędzia prowadzenia polityki historycznej przez samorządy. W pierwszej części tekstu przybliżono aspekty teoretyczne paradyplomacji, czyli polityki zagranicznej samorządów oraz polityki historycznej. Następnie przeprowadzono analizę historycznej polityki zagranicznej samorządów przez pryzmat głównych narzędzi paradyplomacji pamięci, znajdujących się w ich dyspozycji. Całość zaś kończy podsumowanie.

\section{Paradyplomacja i polityka historyczna}

Paradyplomacja stanowi wiodący temat rosnącej liczby rodzimych i zagranicznych opracowań naukowych. Jak wskazuje Tomasz W. Modzelewski, zauważalne zainteresowanie badaczy tą formą polityki zagranicznej zaobserwowano w latach 80 . XX w.5. O ile początkowo koncentrowano się na aktywności międzynarodowej regionów wchodzących w skład państw federalnych, o tyle z początkiem XXI w. nastąpił zwrot ku analizie działalności miast. Mimo to jednoznaczna odpowiedź na pytanie, jak rozumieć paradyplomację, jest praktycznie niemożliwa ${ }^{6}$. Z tego też wzǵlędu jeden z cenionych badaczy tematu, Inaki Aguirre, z przekorą określił ten termin jako „neologizm, który odniósł niespotykany sukces $\mathrm{w}$ literaturze przedmiotu mimo niejasnych właściwości analitycznych"7. W wielu zatem pracach autorzy ograniczają się do stwierdzenia, że paradyplomacja to „udział samorządów w stosunkach międzynarodowych"s. Stąd też w literaturze przedmiotu często zastępowana jest ona przez bliskoznaczne (choć nie zawsze tożsame) terminy, takie jak:

5 W.T. Modzelewski, Dyplomacja bez dyplomatów. Polsko-chorwackie partnerstwa regionalne, "Studia Regionalne i Lokalne” 2020, nr 4(82), s. 97.

6 T. Kamiński, Paradiplomacy - discourse analysis and research conceptualization, [w:] Paradiplomacy in Asia. Case studies of China, India and Russia, red. M. Pietrasiak, G. Bywalec, T. Kamiński, D. Mierzejewski, M. Słowikowski, Wydawnictwo Uniwersytetu Łódzkiego, Łódź 2018, s. 14-17.

7 I. Aguirre, Making sense of paradiplomacy. An intertextual enquiry about a concept in search of a definition, "Regional and Federal Studies” 1999, vol. 9, no. 1, s. 185.

8 A. S. Kuznetsov, Theory and practice of paradiplomacy. Subnational governments in international affairs, Routledge, London-New York 2015, s. 26. 
„mikrodyplomacja”, „dyplomacja regionalna”, „protodyplomacja”, „postdyplomacja” czy też "dyplomacja samorządowa".

Bardziej szczegółowo paradyplomację definiuje natomiast baskijski politolog Noé Cornago. Jak przekonuje, należy ją rozumieć przede wszystkim jako „zaangażowanie rządów subregionalnych w stosunkach międzynarodowych poprzez ustanowienie formalnych i nieformalnych kontaktów, stałych bądź ad hoc, z zagranicznymi publicznymi lub państwowymi podmiotami, w celu promocji socjoekonomicznych, kulturalnych lub politycznych interesów"10. Z kolei zdaniem André Lecoursa paradyplomacja bezpośrednio wiąże się z postępującą decentralizacją władzy i - w konsekwencji - rosnącą rolą regionów oraz miast ${ }^{11}$. Proces ten początkowo objął swoim zasięgiem przede wszystkim zachodnie demokracje liberalne, jednak obecnie można go uznać za występujący globalnie ${ }^{12}$. Szacuje się, że do roku $2050 \mathrm{w}$ miastach będzie żyło dwie trzecie globalnej populacji, a już obecnie wiele z kluczowych problemów międzynarodowych, takich jak migracje, zmiana klimatu czy nierówności społeczne, objawia się szczególnie mocno w centrach miejskich ${ }^{13}$. Należy zatem spodziewać się dalszego wzmocnienia aktywności miast w stosunkach międzynarodowych.

Cele i sposoby realizacji paradyplomacji zależą od uwarunkowań prawnych, kompetencji oraz potencjału jej realizatorów ${ }^{14}$. O ile bowiem

9 A. S. Kuznetsov, Theory and practice of paradiplomacy..., s. 25.

10 N. Cornago, On the normalization of sub-state diplomacy, [w:] Regional sub-state diplomacy today, red. D. Criekemans, Martinus Nijhoff Publishers, Boston 2010, s. 13. Za: B. Curyło, Paradyplomacja. Rozważania na temat wybranych determinant aktywności międzynarodowej regionów, [w:] Artificem commendat opus. Region-pamięć-polityka. Studia i materiały ofiarowane profesor Danucie Kisielewicz, red. E. Ganowicz, Wydawnictwo Uniwersytetu Opolskiego, Opole 2018, s. 78.

11 A. Lecours, Political issues of paradiplomacy. Lessons from the developed world, "International Negotiation” 2002, vol. 7, no. 1, s. 91.

12 Por. M. Goldsmith, Cities in intergovernmental systems, [w:] The Oxford handbook of urban politics, red. P. John, K. Mossberger, S. E. Clarke, Oxford University Press, London and Oxford 2012, s. 133-151.

13 N. Hachigan, Cities will determine the future of diplomacy, „Foreign Policy”, 19 IV 2019 [dostęp: 20 II 2021], dostępny w internecie: <https:/foreignpolicy.com/2019/o4/16/ cities-will-determine-the-future-of-diplomacy/ $\rangle$.

14 Por. H. S. Curto, L. Moita, B. R. Brito, C. Quintas, M. S. Galito, Cities and regions. Paradiplomacy in Portugal, „Janus.net - e-journal of International Relations” 2015, vol. 5, no. 2, s. 108-115. 
w zauważalny sposób wzrasta polityczne znaczenie regionów i miast na arenie międzynarodowej, o tyle $\mathrm{w}$ dalszym ciągu funkcjonują one $\mathrm{w}$ ramach organizmów państwowych, które to wyznaczają kierunek i priorytety polityki zagranicznej. W swojej analizie paradyplomacji Adam Grydehøj wskazuje więc, że może być ona realizowana przez samorządy jedynie pod warunkiem wpisywania się $\mathrm{w}$ całościową politykę państwa. $\mathrm{W}$ przeciwnym razie powstaje bowiem konflikt kompetencji, który zazwyczaj rozstrzygany jest na korzyść władz centralnych ${ }^{15}$. Coraz częściej też państwa podejmują prawne działania $\mathrm{w}$ celu zabezpieczenia własnych interesów przed działalnością międzynarodową samorządów ${ }^{16}$. Paradyplomacja to raczej więc dopełnienie polityki zagranicznej państw aniżeli jej zaprzeczenie ${ }^{17}$. Mimo to, zdaniem niektórych badaczy, instrumentarium paradyplomacji pokrywa się z państwowymi narzędziami polityki zagranicznej. Może być ona realizowana poprzez m.in. polityczną reprezentację za granicą, podpisywanie traktatów międzynarodowych i innych porozumień, tworzenie własnych programów wsparcia i pomocy dla podmiotów zagranicznych, uczestniczenie w organizacjach międzynarodowych oraz innych formalnych i nieformalnych formach współpracy międzynarodowej czy też prowadzenie dyplomacji publicznej ${ }^{18}$.

Paradyplomacja służy jej realizatorom do osiągnięcia konkretnych celów. Za podstawowy należy uznać kreowanie pozytywnego wizerunku miasta czy regionu na arenie międzynarodowej ${ }^{19}$. Promocja wartości, z którymi utożsamia się dany podmiot, stanowi podstawę do osiągnięcia dalszych celów politycznych czy gospodarczych ${ }^{20}$. Soft power jest bowiem „więcej niż tylko

15 A. Grydehøj, Goals, capabilities, and instruments of paradiplomacy by subnational jurisdictions, [w:] Paradiplomacy, red. A. Grydehøj, L. Fabiani, J. S. Ferrando, L. Lopez de Lacalle Aristi, M. Ackrén, Centre Maurits Coppieters, Belgium 2014, s. 16.

16 Por. D. Pejic, A. Kosovac, M. Acuto, New foreign relations bill puts city diplomacy' at risk, „Pursuit" [online], 10 IX 2020 [dostęp: 19 I 2021], dostępny w internecie: $<$ https://pursuit. unimelb.edu.au/articles/new-foreign-relations-bill-puts-city-diplomacy-at-risk $>$.

17 S. Wolff, Paradiplomacy. Scope, opportunities and challenges, „Bologna Center Journal of International Affairs" 2007, vol. 10, s. 141-150.

18 D. Criekmans, Introduction, [w:] Regional sub-state diplomacy today, red. D. Criekmans, Martinus Nijhoff Publisher, Leiden-Boston 2010, s. 45-46.

19 R. Tavares, Paradiplomacy. Cities and states as global players, Oxford University Press, New York 2016, s. 33.

20 Por. M. S. Neves, Paradiplomacy, Knowledge regions and the consolidation of "soft power", „Janus.net. E-journal of International Relations” 2010, vol. 1, no. 1, s. 10-28. 
perswazją lub zdolnością oddziaływania na ludzi za pomocą argumentów, choć jest to jej istotną częścią. Jest ona także zdolnością do przyciągania, a przyciągnięcie często prowadzi do cichego współudziału"21. Dzięki soft power miasta mogą zrealizować swoje pozostałe cele - przede wszystkim odnoszące się do kwestii gospodarczych - takie jak przyciągnięcie nowych inwestycji oraz zwiększenie ruchu turystycznego ${ }^{22}$. Budowa pozytywnego wizerunku na zewnątrz sprzyja ponadto wzmacnianiu wewnętrznej pozycji miasta oraz jego potencjału politycznego. Coraz częściej jednak miasta wykorzystują swoją aktywność dyplomatyczną również do promowania i osiągania konkretnych celów politycznych. To właśnie samorządy inicjują międzynarodową współpracę na rzecz ochrony środowiska, zrównoważonego rozwoju czy rozwiązania kwestii nielegalnej migracji ${ }^{23}$. Nieformalna pozycja miast w międzynarodowym systemie politycznym umożliwia im sprawniejszą reakcję zwłaszcza w tych obszarach, gdzie tempo i zakres podejmowanych decyzji mają kluczowe znaczenie ${ }^{24}$. Praktyka polityczna wskazuje ponadto, że burmistrzom i prezydentom miast łatwiej jest, niż szefom rządów lub głowom państw, upominać się o prawa człowieka oraz wzywać do zawieszenia broni. Co więcej, coraz częściej zdarza się, że paradyplomacja miast zastępuje oficjalną politykę zagraniczną państwa, gdy ta - z różnych powodów - przeżywa trudności lub budzi powszechne kontrowersje ${ }^{25}$.

Jednym z elementów współczesnej polityki zagranicznej, którego znaczenie systematycznie rośnie, jest polityka historyczna ${ }^{26}$. Opiera się ona

21 J.S. Nye jr., Soft power. Jak osiagnąí sukces $w$ polityce światowej, Wydawnictwo Akademickie i Profesjonalne, Warszawa 2007, s. 35.

22 Por. Engaging cities. The growing relevance of soft power to city reputations in Asia Pacific (raport), New York 2014, dostępny w internecie [dostęp: 02 III 2021]: <https://www.webershandwick.com/uploads/news/files/engaging-cities-weber-shandwick-FULLREPORT-s.pdf $>$.

23 S. Curtis, M. Acuto, The foreign policy of cities, „RUSI Journal” 2018, vol. 163, no. 6, s. 5.

24 X. Michon, J. Machano, The future of development is local, „Foreign Policy” [online], 22 I 2020 [dostęp: 21 II 2021], dostępny w internecie: <https://foreignpolicy. com/2020/01/22/sustainable-development-goals-sdgs-think-local-cities/>.

25 I. Daalder, Why cities need their own foreign policies, „Politico”, [online], 6 June 2017, [dostęp: 21 II 2021], https://www.politico.com/magazine/story/2017/o6/o6/ why-cities-need-their-own-foreign-policies-215234/.

26 R. Chwedoruk, Polityka historyczna, Wydawnictwo Naukowe PWN, Warszawa 2018. Por także: O. Barak, „Don't mention war?" The politics of remembrance and forgetfulness in postwar Lebanon, „Middle East Journal” 2007, vol. 61, s. 49-70. 
na koncepcji pamięci zbiorowej, zdefiniowanej przez Maurice'a Halbwachsa jako proces społeczny nakierowany na rzecz upamiętnienia bądź zapomnienia, który formuje tożsamość zbiorową ${ }^{27}$. W obrębie pamięci zbiorowej można wyróżnić pamięć komunikacyjną oraz pamięć kulturową. O ile pierwsza składa się z codziennych interakcji i doświadczeń tzw. świadków historii, o tyle druga jest konstruowana w określonym celu ${ }^{28}$. Tak rozumiana pamięć zbiorowa realizuje zatem trzy podstawowe funkcje w odniesieniu do społeczeństwa: integracyjną, informacyjno-interpretacyjną oraz legitymizacyjno-adaptacyjną ${ }^{29}$. Jak zauważa Edgar Wolfrum, jeden z pionierów badań nad polityką historyczną (niem. Geschichtspolitik), aktorzy polityczni wykorzystują przeszłość do realizacji własnych celów - tak w aspekcie wewnętrznym, jak i zewnętrznym ${ }^{30}$. Innymi słowy polityka historyczna (polityka pamięci) polega na "negocjowaniu przeszłości" przez uczestników życia politycznego ${ }^{31}$. Tym samym dąży ona do takiego kształtowania pamięci zbiorowej, aby „zapewnić wiedzę i schematy interpretacyjne zgodnie z wyznawaną ideologią grupową oraz wzmocnić legitymizację działań przydatnych władzy"32. Do niedawna politykę historyczną postrzegano przede wszystkim przez pryzmat działań skierowanych na wewnątrz, nakierowanych m.in. na konsolidację wspólnoty. Tymczasem przeszłość, jak się okazuje, coraz wyraźniej wpływa także na współczesne stosunki międzynarodowe.

Polityka historyczna jako element polityki zagranicznej spotkała się z zainteresowaniem zarówno historyków, jak i politologów. Zdaniem

27 M. Halbwachs, Społeczne ramy pamięci, Wydawnictwo Naukowe PWN, Warszawa 2008, s. 291.

28 J. Assmann, Pamięć kulturowa. Pismo, zapamiętywanie i polityczna tożsamość w cywilizacjach starożytnych, przeł. A. Kryczyńska-Pham, Wydawnictwo Uniwersytetu Warszawskiego, Warszawa 2008, s. 66.

29 L. M. Nijakowski, Polska polityka pamięci. Esej socjologiczny, Wydawnictwa Akademickie i Profesjonalne, Warszawa 2008, s. 50.

30 E. Wolfrum, Erinnerungskultur und Geschichtspolitik als Forschungsfelder, [w:] Reformation und Bauernkrieg. Erinnerungskultur und Geschichtspolitik im geteilten Deutschland, red. J. Scheunemann, Evangelische Verlagsanstalt, Leipzig 2010, s. 13-47.

31 Por. R. S. Jansen, Resurrection and appropriation. Reputational trajectories, memory work, and the political use of historical figures, „American Journal of Sociology” 2007, nr 112(4), s. 953-1007; E. Zandberg, The right to tell the (right) story, „Media, Culture \& Society" 2010, nr 32(1), s. 5-24.

32 L. M. Nijakowski, Polska polityka pamięci..., s. 51. 
Kathrin Bachleitner model uwzględniający pamięć zbiorową w polityce zagranicznej powinien opierać się na koncepcji dyplomacji emocji. W przeciwieństwie bowiem do tradycyjnego postrzegania stosunków międzynarodowych dyplomacja emocji dąży do zbudowania „określonego obrazu emocji” na arenie międzynarodowej ${ }^{33}$. Podobny cel przyświeca dyplomacji pamięci, gdyż wiąże się ona przede wszystkim z uznaniem pewnej wizji przeszłości przez społeczność międzynarodową. Wydaje się jednak, że w przypadku analizy samorządowej polityki historycznej słuszniej będzie się odnieść do prac Hansa Henninga Hahna, który jako jeden z pierwszych podjął próbę stworzenia podstaw teoretycznych tzw. dyplomacji pamięci. W swojej koncepcji „transgranicznej polityki pamięci” niemiecki badacz nawiązywał do idei historii transnarodowej, podkreślając jej dyskursywny charakter. Jego zdaniem polityka historyczna jako element polityki zagranicznej "stanowi w debacie nad tożsamością innego społeczeństwa próbę włączenia się w spory o władzę" ${ }^{\text {"34 }}$. Co ważne, „transgraniczna polityka pamięci” nie jest prowadzona równymi środkami, a „spory toczące się za ich pośrednictwem nie przebiegają według reguł uczciwego fair play"35. Oznacza to, że podlega ona tym samym uwarunkowaniom co pozostałe sfery polityki zagranicznej. Podobnie jak większość badaczy polityki historycznej, Hahn koncentruje się na relacjach międzypaństwowych, choć zaznacza, że w wymiarze międzynarodowym „odbiorcami” polityki historycznej są głównie społeczeństwa. Z tego też powodu koncepcja „transgranicznej polityki pamięci" wydaje się być atrakcyjna dla analizy tego zjawiska również $\mathrm{w}$ wymiarze pozapaństwowym Jednak w interesującym nas przypadku miast należy doprecyzować, że za zagraniczną politykę historyczną uznaje się jedynie te działania, które realizowane są przez oficjalne władze samorządowe lub instytucje im podległe. Rozróżnienie to jest tym istotniejsze,

33 K. Bachleitner, Diplomacy with memory. How the past is employed for future foreign policy, „Foreign Policy Analysis” 2019, no. 15, s. 495.

34 H.H.Hahn, Polityka historyczna a stosunki binarodowe. Głos na rzecz stworzenia kodeksu zachowań w polityce pamięci, [w:] Polsko-niemieckie miejsca pamięci, t. 4, red. R. Traba, H. H. Hahn, Wydawnictwo Naukowe Scholar, Warszawa 2013, s. 157.

35 H. H. Hahn, Pamięć zbiorowa - przedmiot polityki historycznej?, [w:] Narodowe i europejskie aspekty polityki historycznej, red. B. Korzeniewski, Wydawnictwo Instytutu Zachodniego, Poznań 2008, s. 41. 
że w przypadku lokalnej polityki historycznej można mówić o szerokim spektrum podmiotów owej polityki ${ }^{36}$.

Według Katarzyny Kąckiej wyróżnia się cztery podstawowe narzędzia realizowania polityki historycznej. Pierwszym z nich jest zagospodarowanie przestrzeni symbolicznej, m.in. poprzez celebrację odpowiednich świąt czy też budowę (lub demontaż) pomników. Te ostatnie zaliczane są do tzw. nośników pamięci, odgrywających kluczową rolę w popularyzacji odpowiedniej narracji - wewnątrz i na zewnątrz ${ }^{37}$. Następnym narzędziem, o którym wspomina badaczka, są instytucje pamięci, a więc finansowane ze środków państwowych lub samorządowych placówki zajmujące się „szeroko pojętą sferą memoryzacji” ${ }^{\prime 38}$. Do tej grupy należą przede wszystkim muzea, centra kultury i inne ośrodki, których głównym zadaniem jest popularyzacja usankcjonowanej wersji historii. Za kolejny instrument realizacji polityki historycznej należy uznać system edukacji i nauki. Poprzez odpowiedni dobór podręczników i lektur państwo może kształtować pożądane wzorce zachowań oraz tworzyć katalog postaci i wydarzeń z przeszłości. Wymiar sprawiedliwości stanowi czwarte narzędzie polityki historycznej. Wymienione instrumenty znajdują zastosowanie przede wszystkim w wymiarze wewnętrznym i nie wyczerpują spektrum możliwości stojących przed realizatorami polityki historycznej. Z pewnością należałoby uzupełnić listę m.in. o nowe elementy, takie jak media masowe - zwłaszcza internetowe - czy też produkty kultury popularnej (np. film, książka) do budowania odpowiedniej narracji o przeszłości ${ }^{39}$. Co więcej koniecznym jest dostosowanie wymienionych narzędzi do specyfiki funkcjono-

36 R.Zenderowski, Polityki pamięci w miastach podzielonych granica państwowa. Teoretyczne i metodologiczne ramy badań, [w:] Lokalne polityki pamięci $w$ mieście podzielonym granica państwowa, red. R.Zenderowski, Wydawnictwo UKSW, Warszawa - Cieszyn 2021, s. 21. Por. także: Ł. Skoczylas, Lokalne polityki pamięci, „Środkowoeuropejskie Studia Polityczne" 2015, nr 4, s. 251.

37 A. Szpociński, Współczesna kultura historyczna $i$ jej przemiany, Wydawnictwo Naukowe Scholar, Warszawa 2021, s. 94-96.

38 K. Kącka, Polityka historyczna. Kreatorzy, narzędzia, mechanizmy - przykład Polski, [w:] Narracje pamięci. Między polityka a historia, red. K. Kącka, J. PiechowiakLamparska, A. Ratke-Majewska, Wydawnictwo Uniwersytetu Mikołaja Kopernika, Toruń 2015, s. 72.

39 N. Maurantonio, The politics of memory, [w:] The Oxford handbook of political communication, red. K. Kenski, K. H. Jamieson, Oxford University Press, Oxford 2014, s. 219-236. 
wania samorządów, których kompetencje w tej mierze są przecież mocno ograniczone, nawet w przypadku państw federalnych. Warto zatem traktować owo instrumentarium nie jako skończony zbiór, lecz raczej jako zestaw podstawowy, za pomocą którego podmioty pozapaństwowe mogą realizować politykę historyczną. Tak jest w przypadku poniższej analizy, gdzie ów zestaw służy do zilustrowania aktywności samorządów w obszarze paradyplomacji pamięci.

\section{Paradyplomacja miast przez zagospodarowanie przestrzeni publicznej}

Przestrzeń publiczna stanowi podstawowy element funkcjonowania mia$\mathrm{sta}^{40}$. Należy ją rozumieć nie tylko jako fizyczną lokalizację $\mathrm{w}$ strukturze przestrzeni miejskiej, ale także jako kategorię uwzględniającą „znaczenie tożsamości kulturowej, poczucia bezpieczeństwa oraz zrozumiałości i przejrzystości"41 . Niektórzy badacze wręcz utożsamiają miasto z przestrzenią publiczną ${ }^{42}$. W kontekście tematyki niniejszego artykułu należy jednak spojrzeć na przestrzeń publiczną przede wszystkim jako na sferę polityczną, gdzie manifestuje się pamięć zbiorowa danej społeczności. Powtarzając za Beatą Malinowską-Petelenz i Anną Petelenz, można stwierdzić, że „przestrzeń publiczna, w której toczy się codzienność, tworzy niezbędny element naszego życia, łączy emocje i obrazy, na długo pozostając w pamięci"43. Jak już wspomniano, lokalna polityka historyczna realizowana jest głównie poprzez określone nazewnictwo ulic i placów, stawianie (lub usuwanie) pomników oraz sankcjonowanie pozostałych miejsc pamięci. W swojej podstawowej funkcji oddziałują one na wewnątrz, to znaczy budują tożsamość i pamięć zbiorową lokalnej społeczności. Niemniej mogą być wykorzystane także w aktywności zagranicznej samorządów.

40 Por. J. A. Drzewiecka, T. K. Nakayama, City sites. Postmodern urban space and the communication of identity, „Southern Communication Journal” 1998, vol. 64, issue 1, s. 20-31.

41 K. Bierwiaczonek, Przestrzeń publiczna jako przestrzeń tożsamości miasta. Szansa czy balast dla rozwoju miasta?, "Acta Universitatis Lodziensis” 2015, nr 54, s. 62.

42 N. Krzyżanowska, Dyskursy (nie) pamięci w przestrzeni miasta, „Studia Socjologiczne” 2016, nr 1(220), s. 128; por. M. Ch. Boyer, The city of collective memory. Its historical imagery and architectural entertainments, MIT Press, Cambridge 1994.

43 B. Malinowska-Petelenz, A. Petelenz, Przestrzeń publiczna jako ekspresja pamięci, „Architektura. Czasopismo Techniczne” 2010, z. 6, s. 26. 
Decyzja o takim, a nie innym zagospodarowaniu symbolicznym przestrzeni miejskiej może być ponadto podyktowana czynnikami zewnętrznymi. Jednym z prekursorów dyplomacji pamięci było japońskie miasto Hiroszima, którego tragiczna historia miała służyć jako ostrzeżenie przed ponownym użyciem broni atomowej. Współczesny miejski krajobraz pamięci, oddziałujący na społeczność międzynarodową, tworzy nie tylko z kompleks Parku Pamięci Pokoju (ukończony w 1964 r.), ale przede wszystkim zespół ruin, pozostawionych w nienaruszonej formie - na mocy porozumienia władz państwowych i lokalnych - od 6 sierpnia 1945 r. $^{44}$. Począwszy od 1947 r., w rocznicę tego wydarzenia władze Hiroszimy organizują okolicznościowe uroczystości przed pamiątkowym grobowcem, w których biorą udział delegacje z całego świata. W sierpniu 1949 r. w pierwszym w dziejach Japonii referendum mieszkańcy miasta w zdecydowanej większości (ponad 90 proc.) opowiedzieli się za budową Parku, którą następnie prowadziły i nadzorowały władze Hiroszimy. Sam zaś teren został przekazany miastu przez rząd centralny na mocy specjalnej ustawy (Heiwa Kinen Toshi Kensetsuhõ) ${ }^{45}$. Wyjątkowego znaczenia nabrały rocznicowe obchody w 2010 r., kiedy po raz pierwszy uczestniczył w nich przedstawiciel administracji amerykańskiej ${ }^{46}$.

Innym przykładem wykorzystania przestrzeni symbolicznej dla osiągania celów w samorządowej polityce zagranicznej jest Pomnik Pomordowanych Żydów Europy (niem. Denkmal für die emordeten Juden Europas), autorstwa Petera Eisenmana, w Berlinie. W połowie 1999 r. Bundestag zgodził się na powstanie pomnika, a przeprowadzenie konkursu na projekt oraz nadzór nad jego budową powierzono komisji, w skład której wchodzili m.in. przedstawiciele stołecznego senatu ${ }^{47}$.

44 Por. H.Okuda, Remembering the atomic bombing of Hiroshima and Nagasaki. Collective memory of post-war Japan, „Acta Orientalia Vilnensia” 2011, vol. 12, no. 1, s. 11-28; L. Yoneyama, Hiroshima traces. Time, space, and the dialectics of memory, University of California Press, Oakland 1999, s. 43-65.

45 O. Beazley, A paradox of peace. The Hiroshima Peace Memorial (Genbaku Dome) as world heritage, [w:] A fearsome heritage. Diverse legacies of the cold war, red. J. Schofield, W. Cocroft, Routledge, New York 2016, s. 35-36.

46 M. Fackler, At Hiroshima ceremony, a first for a U. S. envoy, "The New York Times”, 7 VIII 2010, s. A4.

47 J. E. Young, Berlin's Holocaust Memorial. A report to the Bundestag Committee on Media and Culture 3 March 1999, "German Politics \& Society” 1999, vol. 17, no. 3(52), s. 54-70. 
Odsłonięty w 2005 r. pomnik miał za zadanie nie tyle oddziaływać na pamięć zbiorową samych berlińczyków i Niemców, co przede wszystkim kształtować odpowiednią narrację historyczną na arenie międzynarodowej. Co więcej, tak monumentalne - a zarazem symbolicznie niejednoznaczne - miejsce pamięci podkreślało nowy stołeczny charakter Berlina, który od 1999 r. na powrót stał się siedzibą federalnego rządu i parlamentu ${ }^{48}$. Warto zauważyć, że o ile inicjatywa budowy pomnika, jak też jego powszechny wydźwięk były inspirowane przez Bundestag, o tyle jego dalsze wykorzystanie należy do władz miejskich ${ }^{49}$.

Kolejnym przykładem tworzenia miejsc pamięci do wzmocnienia międzynarodowego wizerunku miasta jest Narodowy Pomnik i Muzeum 11 Września w Nowym Jorku (ang. National September 11 Memorial \& Museum $)^{50}$.Za budowę pomnika i muzeum, którą ukończono w dziesiątą rocznicę zamachów terrorystycznych, odpowiadała The Lower Manhattan Development Corporation (LMDC), specjalna jednostka powołana przez władze stanowe oraz miejskie. Obecnie LMDC sprawuje pieczę nad całością terenu dawnego World Trade Center ${ }^{51}$. Podobnie jak w przypadku Hiroszimy i Berlina, także i amerykańska metropolia tworzy narrację świadomego swojej historii miasta poprzez odwołanie do tragicznych wydarzeń ${ }^{52}$.

Powyższe przykłady dotyczą metropolii, a więc miast, których możliwości gospodarcze i polityczne predestynują je do odgrywania samodzielnej roli na arenie międzynarodowej. Jak bowiem dowodzi część badaczy, potencjał największych i najzamożniejszych ośrodków miejskich dorównuje potencjałowi państw narodowych, a w niektórych przypadkach nawet

48 Ł. Posłuszny, Miejsca pamięci. Przestrzeń - pamiętanie - zapominanie w kontekście Pomnika Pomordowanych Żydów Europy, [w:] Miejsca pamięci w świadomości współczesnego człowieka, red. K. Zieliński, J. Janikowska, Wydawnictwo Akapit, Toruń 2015, s. 134 .

49 Por. E. Neumärker, Germany's Memorial to the Murdered Jews of Europe. Debates and reactions, „Filozofija i Druŝtvo” 2012, vol. XXIII, no. 4, s. 139-147.

50 Muzeum poświęcone zamachom 11 września 2001 r. zainaugurowało swoją działalność 15 maja $2014 \mathrm{r}$.

51 G. Key, New York after 9/11 and the new WTC designs, [w:] Cities full of symbols. A theory of urban space and culture, red. P. J. M. Nas, Leiden University Press, Amsterdam 2011, s. 275.

52 A. Sodaro, Prosthetic trauma and politics in the National September 11 Memorial Museum, „Memory Studies” 2019, vol. 12, no. 2, s. 117-129. 
je przewyższa ${ }^{53}$. Warto także podkreślić, że wiele ze stołecznych miejsc pamięci powstało $\mathrm{z}$ inicjatywy władz centralnych, dlatego też ich funkcjonowanie należałoby raczej postrzegać przez pryzmat państwowej polityki historycznej niż wyłącznie samorządowej. Trudno zatem dziwić się, że przestrzeń symboliczna Hiroszimy, Berlina, Nowego Jorku, Londynu czy Paryża z równą siłą oddziałuje na pamięć zbiorową zarówno swoich mieszkańców, jak i ponadnarodowej społeczności.

Jednak wykorzystanie przestrzeni symbolicznej do realizacji celów polityki zagranicznej to nie tylko domena światowych metropoliii ${ }^{54}$. Do prekursorów pod tym względem należą bowiem miasta pogranicza. Położenie geograficzne oraz (zazwyczaj) wielonarodowa i wielokulturowa historia tych ośrodków umożliwiają im oparcie własnej strategii promocji na międzynarodowej współpracy. Dotyczy to nie tylko tzw. miast podzielonych czy stykowych $^{55}$, ale też - w polskim przypadku - ogółu ośrodków położonych w obszarze pogranicznym, z uwzględnieniem także ośrodków znajdujących się w pewnej odległości od pasa granicznego, lecz na niego oddziałujących, jak np. Wrocław, Lublin, Rzeszów, Gdańsk czy Opole ${ }^{56}$.

Poprzez odwołanie do wspólnego dziedzictwa, chociażby w postaci odrestaurowanych budynków, parków itp., polskie miasta przyǵraniczne angażują własną przestrzeń do dialogu z partnerami z drugiej strony granicy. Jak wskazuje Magdalena Szalbot, „dwumiejskość” tego typu ośrodków „może stanowić nie tylko atrakcję turystyczną, ale również ważny aspekt tożsamości społeczno-kulturowej tych miejscowości" ${ }^{\prime 57}$. Rozpatrując zaś przestrzeń publiczną jako sferę oddziaływania polityki historycznej, można także mówić o „dwumiejskim" charakterze pamięci zbiorowej miast pogranicza. Za przykład może posłużyć Gorzów Wielkopolski, ośrodek położony w województwie lubuskim,

53 S. Curtis, The meaning of global cities. Rethinking the relationship between cities, states, and international order, [w:] The power of cities in international relations, red. S. Curtis, Routledge, New York 2014, s. 16-31.

54 Por. M.Zaborski, Współczesne pomniki i miejsca pamięci w polskiej i niemieckiej kulturze politycznej, Wydawnictwo Adam Marszałek, Torun 2011, s. 259.

55 K. Kulczyńska, Miasta podzielone jako przedmiot zainteresowań geografii oraz innych nauk, „Rozwój Regionalny i Polityka Regionalna” 2013, nr 24, s. 49.

56 Ch. Grabowski, The city as a lieu de mémoire, „The Polish Review” 2018, vol. 63, no. 3, s. $35-48$.

57 M. Szalbot, Społeczno-kulturowa specyfika przygranicznych miast podwójnych Europy jako problem badawczy, „Studia Etnologiczne i Antropologiczne” 2011, nr 11, s. 149. 
realizujący od początku lat dziewięćdziesiątych XX w. politykę bliskiej współpracy z partnerami niemieckimi ${ }^{58}$. Dążąc do zacieśnienia dwustronnych relacji, w 1997 r. z inicjatywy gorzowskich władz odbudowano tzw. fontannę Pauckscha, zdemontowaną na cele wojenne w 1941 r. Z kolei we wrześniu 2006 r., rozpoczynając 750 . rocznicę lokalizacji miasta, na dawnym pomniku Braterstwa Broni (wcześniej zdemontowano z niego czerwoną gwiazdę) zainstalowano tzw. Dzwon Pokoju, sfinansowany przez byłych i obecnych mieszkańców Landsberga/ Gorzowa. Obecnie pomnik ten stanowi miejsce spotkań tych dwóch społeczności podczas Dnia Pamięci i Pojednania, który zastąpił dotychczasowe święto zdobycia miasta przez Armię Czerwoną 10 stycznia 1945 r. Przykłady podobnych inicjatyw można mnożyć. Intensywna współpraca $w$ regionie pogranicza doprowadziła do wytworzenia się zrębów transgranicznej polityki pamięci, o której już wspomniano, a która uwzględnia racje historyczne obu stron ${ }^{59}$. W celu dodatkowej ilustracji omawianej tendencji można wskazać takie ośrodki jak Kaliningrad ${ }^{60}$ i Wyborg ${ }^{61}$. Przypadek tych dwóch rosyjskich miast jest o tyle ciekawy, że realizowana przez nie polityka pamięci, nakierowana na zachowanie wielokulturowego dziedzictwa, często wchodzi w konflikt z polityką prowadzoną przez władze państwowe. Nie wolno przy tym zapominać, że przestrzeń pamięci miast pogranicza ma także większy potencjał konfliktogenny niż w przypadku ośrodków położonych w mniej peryferyjnych regionach ${ }^{62}$.

Trzeba zatem wspomnieć - o czym była już mowa we wstępie - o celowych zmianach $\mathrm{w}$ przestrzeni symbolicznej miast, które prowadzą nie do wzmocnienia współpracy, lecz do konfliktu. Przykładem takich skutków

58 Por. K. Wasilewski, Między Nową Marchią a Wołyniem. O lokalnej polityce historycznej i pamięci zbiorowej mieszkańców Gorzowa Wielkopolskiego, „Przegląd Zachodni” 2019, nr 3, s. 37-54.

59 H. H. Hahn, Pamięć zbiorowa..., s. 33.

60 M. Łuniewski, Bursztynowy separatyzm, "Plus - Minus" 2019, nr 5, s. 24-25.

61 J.Semi, Representing the places of Vyborg. Town space as lieux de memoire, Paper presented at the European Association of Urban History Conference, Helsinki, 24-27 August 2016, dostępny w internecie [dostęp: 21 II 2021]: <https://www.researchgate.net/publication/307475724>.

62 Por. T. Stryjek, V. Sklokin, Wprowadzenie. Kultury historyczne. O niepowodzeniu pojednania historycznego z nowej perspektywy, [w:] T. Stryjek, V. Sklokin, Kultury historyczne Polski i Ukrainy. O źródłach nieporozumienia między sąsiadami, Wydawnictwo Naukowe Scholar, Collegium Civitas, Warszawa 2021, s. 8-9. 
paradyplomacji pamięci jest demontaż Kolumny Zwycięstwa z 1945 r., dokonany przez władze miejskie Stargardu w listopadzie $2016 \mathrm{r}^{63}$. Chociaż podobne decyzje podjęło $\mathrm{w}$ tym czasie wiele samorządów, likwidacja stargardzkiego pomnika wywołała zdecydowaną odpowiedź ze strony rosyjskiego ministerstwa spraw zagranicznych, które wystosowało w tej sprawie oficjalne oświadczenie ${ }^{64}$. $\mathrm{Z}$ podobną reakcją ze strony władz Federacji Rosyjskiej spotkało się m.in. usunięcie Pomnika Wdzięczności Armii Czerwonej, który od $1950 \mathrm{r}$. znajdował się w centrum Szczecina ${ }^{65}$. Chociaż w obu wskazanych przypadkach władze miejskie działały w odpowiedzi na nowe zapisy w ustawodawstwie państwowym, decyzje przez nie podjęte były autonomiczne i wpisywały się w założenia ich polityki historycznej ${ }^{66}$. Ze sprzeciwem władz polskich spotkała się natomiast próba zmiany lokalizacji Pomnika Katyńskiego w Jersey City w USA (Katyn Memorial in Jersey City). Odsłonięty w 1990 r. był pierwszą próbą upamiętnienia w Stanach Zjednoczonych mordu na polskich oficerach ${ }^{67}$. Ze względu jednak na swoją bezpośrednią formę od początku spotykał się ze słowami krytyki ze strony części mieszkańców Jersey City i jego władz. W konsekwencji w maju 2018 r. rada miasta zapowiedziała jego przeniesienie z reprezentacyjnego placu ${ }^{68}$.

63 Uchwała nr XXIV/254/2016 Rady Miejskiej w Stargardzie z dnia 29 listopada 2016 r. w sprawie demontażu Pomnika Zwycięstwa, zlokalizowanego na Placu Wolności w Stargardzie.

64 akr, Rosja oburza demontażem sowieckiego pomnika w Stargardzie, „Gazeta Wyborcza” [online], 2 XII 2016, [dostęp: 03 III 2021], dostępny w internecie: <https://szczecin.wyborcza.pl/szczecin/1,34939,21061393,rosja-oburzona-demontazem-sowieckiego-pomnika-w-stargardzie.html $>$.

65 Uchwała Nr XIX/459/2016 Rady Miasta Szczecina z dnia 17 maja 2016 roku w sprawie usunięcia pomnika Wdzięczności dla Armii Czerwonej w Szczecinie. Por. także: D. Czarnecka, „Pomniki wdzięczności” Armii Czerwonej w Polsce Ludowej i w III Rzeczypospolitej, Instytut Pamięci Narodowej, Warszawa 2015, s. 269.

66 Dz.U. 2017 poz. 1389, Ustawa z dnia 22 czerwca 2017 r. o zmianie ustawy o zakazie propagowania komunizmu lub innego ustroju totalitarnego przez nazwy budowli , obiektów i urządzeń użyteczności publicznej.

67 A. Jasiński, Kronika New Jersey. Uroczystości katyńskie w New Jersey, „Nowy Dziennik" [online], 21 IX 2009 [dostęp: 20 III 2021], dostępny w internecie: $\langle$ http:// dziennik.com/polonia/kronika-new-jersey-uroczystosci-katynskie-w-jersey-city/ $\rangle$.

68 R. Rojas, Jersey City argues over a statue, and politicians in Poland weigh in, „The New York Times", 12 V 2018, s. 19. 
Decyzja ta została oficjalnie skrytykowana przez najwyższe polskie władze, a 16 maja 2018 r. kwiaty pod pomnikiem złożył prezydent Andrzej Duda. Ostatecznie, w wyniku sprzeciwu części radnych miejskich oraz zorganizowanych grup mieszkańców Jersey City (nie tylko polskiego pochodzenia), pomnik pozostał na dotychczasowym miejscu ${ }^{69}$.

\section{Instytucje pamięci}

Państwa realizują własną politykę historyczną m.in. za pośrednictwem instytucji odpowiedzialnych za popularyzację określonej narracji na temat przeszłości. Tradycyjnie taką rolę pełnią muzea, których podstawowym zadaniem jest „organizacja pamięci” w skali regionalnej, krajowej i międzynarodowej ${ }^{70}$. Zagraniczny sukces rodzimych placówek, takich jak Muzeum Historii Żydów Polskich Polin ${ }^{71}$ i Muzeum Drugiej Wojny Światowej, dowodzi, że mogą one pełnić ważną funkcję w dyplomacji, zarówno w odniesieniu do relacji międzyrządowych, jak i budowy pozytywnego wizerunku państwa wśród zagranicznych społeczeństw. Obok muzeów rządy coraz częściej powołują specjalne instytucje o charakterze „ofensywnym”, z podstawowym celem kreowania polityki historycznej w kraju i za granicą ${ }^{72}$. Za przykład może posłużyć Instytut Pamięci Narodowej, a także funkcjonujący krócej i na mniejszą skalę Instytut Dziedzictwa Myśli Narodowej im. Romana Dmowskiego i Ignacego Paderewskiego czy Instytut Pileckiego. Naturalnie samorządy mają o wiele skromniejsze możliwości kreowania własnej polityki historycznej. Podstawowym narzędziem oddziaływania

69 Por. K. Lowe, Prisoners of history. What monuments to World War II tell us about our history and ourselves, St. Martin's Press, New York 2020, s. 117-129.

70 K. A. Gajda, Muzeum jako nośnik pamięci, [w:] Muzeum a pamięć. Forma, produkcja, miejsce, red. T. F. Rosset, E. Doiczmanowa-Bednarz, A. Tołysz, Nimoz, Warszawa 2018, s. 73.

71 Muzeum Historii Żydów Polskich Polin jest instytucją kultury współprowadzoną przez miasto stołeczne Warszawa oraz ministra właściwego sprawom kultury i ochrony dziedzictwa narodowego. Jest to więc przykład państwowo-samorządowej instytucji pamięci, która ze względu na zakres tematyczny wpisuje się w centralną politykę historyczną. Por. Statut Muzeum Historii Żydów Polskich Polin.

72 Por. A. Wójcik, Polityka historyczna jako forma budowy wizerunku Polski na arenie międzynarodowej, „Świat Idei i Polityki” 2016, nr 15, s. 448. 
miast na lokalną społeczność są muzea, domy kultury i biblioteki ${ }^{73}$. To właśnie one należą do kluczowych instytucji pamięci w wymiarze lokalnym - posiadają bowiem wykształconą i doświadczoną kadrę, dzięki czemu mogą realizować projekty nakierowane na popularyzację odpowiedniej narracji historycznej, również w aspekcie międzynarodowym.

Muzeum Powstania Warszawskiego ${ }^{74}$ to prawdopodobnie najbardziej znany rodzimy przykład samorządowej instytucji pamięci o międzynarodowym zasięgu. Kolejnym z muzeów powołanym przez samorząd, które ma za zadanie kształtowanie polityki historycznej także za granicą, jest Europejskie Centrum Solidarności w Gdańsku ${ }^{75}$. Jak można bowiem przeczytać na stronie internetowej tej instytucji, powstałej w 2007 r. „chcemy zachować w pamięci Polaków i Europejczyków doświadczenie Solidarności jako pokojowej europejskiej rewolucji, aby we wspólnocie europejskich demokracji Solidarność była ważną częścią mitu założycielskiego Europy" ${ }^{n 6}$. Muzeum realizuje tak zdefiniowaną misję poprzez organizowanie międzynarodowych konferencji i seminariów, angażowanie zagranicznych i rodzimych naukowców, wydawanie anglojęzycznych publikacji itp. W centrum powyższych inicjatyw znajduje się zaś miasto Gdańsk, przedstawiane jako kolebka współczesnej demokracji i ruchów wolnościowych ${ }^{77}$. Podobny cel przyświeca działalności Centrum Dialogu Przełomy wchodzącego w skład Muzeum Narodowego w Szczecinie. Co prawda jest to samorządowa instytucja kultury, prowadzona wspólnie przez odpowiedni organ centralny i wojewódzki $^{78}$, lecz służy ona głównie władzom miejskim, których przedstawiciele

73 A. Assmann, Transformations between history and memory, „Social Research” 2008, vol. 75 , s. 56 .

74 Uchwała nr XxxVi/886/2012 Rady Miasta Stołecznego Warszawy z dnia 17 maja 2012 r. zmieniająca uchwałę w sprawie utworzenia i nadania statutu Muzeum Powstania Warszawskiego. Por. także: I. Kurz, Przepisywanie pamięci. Przypadek Muzeum Powstania Warszawskiego, „Kultura Współczesna” 2007, nr 3(53), s. 150-162.

75 P. Adamowicz, Cz. Bielecki, T.T.Głuszko, Europejskie Centrum Solidarności, "Przegląd Polityczny” 2005, nr 73/74, s. 58-64.

76 Misja Ecs: Poznaj historię, zadecyduj o przyszłości, Europejskie Centrum Solidarności, [dostęp: o8 III 2021], dostępny w internecie: 〈https://ecs.gda.pl/title,Misja,pid,29.html〉.

77 Por. B. Kerski, K. Żelazek, Europejskie Centrum Solidarności. Portret pierwszego dziesięciolecia, Europejskie Centrum Solidarności, Gdańsk 2017.

78 Uchwała nr vi/75/19 Sejmiku Województwa Zachodniopomorskiego z dnia 25 kwietnia 2019 r. w sprawie nadania statutu Muzeum Narodowemu w Szczecinie. 
uczestniczą m.in. w wyborze Rady Muzeum i opracowywaniu planów działalności ${ }^{79}$. Samo muzeum stanowi zaś „miejsce spotkań i dyskusji na tematy dotyczące najnowszej historii miasta, regionu, Polski i Europy", utrzymane „w duchu wielokulturowego, transgranicznego dialogu i współpracy" ${ }^{\prime \prime 0}$. Podstawowym celem Centrum Dialogu Przełomy jest ukazanie Szczecina jako miasta, w którym narodziła się Solidarność, miasta nieujarzmionego, któremu nie zdołano w pełni narzucić komunistycznej władzy. Sam zaś samorząd nie ukrywa, że muzeum ma służyć tworzeniu pozytywnego wizerunku miasta i regionu za granicą ${ }^{81}$. Swoisty „boom muzealny” wykorzystują także inne miasta. We wrześniu $2021 \mathrm{r}$. w Białymstoku ma rozpocząć działalność Muzeum Pamięci Sybiru jako samorządowa miejska instytucja kultury $^{82}{ }^{83}$. Biorąc pod uwagę przygraniczne położenie tej placówki, dysponuje ona odpowiednim potencjałem, aby uczestniczyć w polityce historycznej nie tylko w kontekście regionalnym, ale i międzynarodowym.

Również mniejsze miasta wykorzystują instytucje kultury do prowadzenia dyplomacji pamięci. Jak już wspomniano, do szczególnie uprzywilejowanych pod tym względem należą instytucje funkcjonujące na pograniczu, których współpraca $\mathrm{z}$ partnerami zagranicznymi wspierana jest przez różnego rodzaju środki finansowe z Unii Europejskiej ${ }^{84}$. Większość takich projektów na pograniczu, w tym i tych odnoszących się do polityki historycznej, realizuje się w ramach tzw. euroregionów. Zgodnie z definicją

79 Uchwała Zarządu Województwa Zachodniopomorskiego nr 1315/10 z dnia 26 lipca 2010 r. w sprawie powołania członków Rady Muzeum działającej przy Muzeum Narodowym w Szczecinie.

80 Misja/statut, Muzeum Narodowe w Szczecinie, [dostęp: o8 III 2021], dostępny w internecie: 〈https://muzeum.szczecin.pl/o-muzeum/misja-statut.html $>$.

81 A. Kuchcińska-Kurcz, Centrum Dialogu Przełomy - w stronę publiczności muzealnej, "Materiały Zachodniopomorskie" 2018, t. XIV, s. 437-463.

82 Uchwała nr XLIII/674/17 Rady Miasta Białystok z dnia 27 listopada 2017 r. w sprawie ogłoszenia tekstu jednolitego uchwały w sprawie nadania statutu Muzeum Pamięci Sybiru - Muzeum w organizacji.

83 Por. Czy we Wrocławiu powstanie Muzeum Kresów Wschodnich?, "Gazeta Wyborcza” [online], 01 II 2011 [dostęp: 10 III 2021], dostępny w internecie: <https://wroclaw. wyborcza.pl/wroclaw/1,35771,9033220,Czy_we_Wroclawiu_powstanie_Muzeum_ Kresow_Wschodnich_html $>$.

84 Cz. Osękowski, H. Szczegóła, Euroregiony na pograniczu polsko-niemieckim (19911997), Lubuskie Towarzystwo Naukowe, Zielona Góra 1998, s. 10. 
euroregiony to „zinstytucjonalizowane związki formalne pomiędzy organizacjami państwowymi lub samorządowymi bądź nieformalnie tworzone przez stowarzyszenia zawodowe, naukowe, kulturalne itp. w celu rozwijania współpracy na obszarach przygranicznych" ${ }^{\text {"85 }}$. Euroregiony stanowią zatem bezpośredni efekt współpracy transgranicznej, a co ważniejsze, wyznaczają pewien nowy, międzynarodowy obszar oddziaływania lokalnych instytu$\mathrm{cji}^{86}$. Pierwszym euroregionem utworzonym w Polsce był Euroregion Nysa, kolejne zaś powstawały przede wszystkim na ścianie zachodniej, m.in. Pro Europa Viadrina (grudzień 1993 r.) oraz Euroregion Sprewa-Nysa-Bóbr (wrzesień 1993 r.). Szczególnym narzędziem do prowadzenia polityki historycznej w ramach euroregionów był i pozostaje Fundusz Małych Projektów Phare $\mathrm{CBC}^{87}$. Realizowane projekty wpisują się $\mathrm{w}$ politykę wzmacniania relacji sąsiedzkich, lecz nie sposób nie zauważyć, że przy okazji kreują one specyficzną narrację historyczną. Polskie muzea i biblioteki, jako najczęściej wiodący partnerzy, przypominają wielokulturowe i wieloetniczne dziedzictwo pogranicza, przywołując osoby i wydarzenia z przeszłości należące do kanonu pamięci nie tylko jednego narodu. W wielu przypadkach daje się jednak zauważyć asymetrię $\mathrm{w}$ działaniach nakierowanych na upamiętnienie wielokulturowego dziedzictwa, o której wspominał Hahn. Trudno zatem ocenić, w jakim stopniu tak kształtowana polityka historyczna stanowi efekt świadomego działania polskich samorządów na pograniczu, w jakim zaś wynika $\mathrm{z}$ indywidualnej inicjatywy pracowników instytucji ${ }^{88}$.

\section{System edukacji i nauki oraz prawodawstwo}

Ograniczona rola polskich samorządów w kształtowaniu systemu edukacji i nauki sprawia, że to narzędzie polityki historycznej pozostaje domeną władz centralnych. To właśnie one odpowiadają chociażby za zawartość

85 Cz. Osękowski, H. Szczegóła, Euroregiony na pograniczu..., s. 10.

86 W. Malendowski, M. Szczepaniak, Rola euroregionów w procesie integracji europejskiej, [w:] Euroregiony mosty do Europy bez granic, Dom Wydawniczy Elipsa, Warszawa 2000, s. 11.

87 K. Szydłak, Zarządzanie Funduszem Małych Projektów (FMP) Phare CBC w Euroregionie „Pro Europa Viadrina”, Pro Europa Viadrina, Gorzów Wlkp. 2001.

88 Por. K. Wasilewski, Zjednoczenie Niemiec a transkulturacja polityki historycznej i pamięci zbiorowej mieszkańców pogranicza polsko-niemieckiego na przykładzie Ziemi Lubuskiej, „Rocznik Polsko-Niemiecki” 2020, nr 28, s. 222-224. 
podręczników, uważanych za podstawowy nośnik wiedzy naukowej oraz socjalizacji politycznej. Jak wskazuje Jolanta Michalak, „tematyka, wybór tekstów, ale także ilości materiału dotyczącego danego zagadnienia są regulowane odgórnymi założeniami programowymi, ilością godzin przeznaczonych na lekcje danego przedmiotu" ${ }^{89}$. Nic zatem dziwnego, że państwo posiada monopol na dopuszczanie konkretnych publikacji do użytku szkolnego i ustalania ich treści. Jedynie w niektórych systemach federalnych kompetencje te przekazane zostały na poziom regionalny ${ }^{90}$. Zgodnie z polskim prawodawstwem rola samorządu sprowadza się głównie do finansowania i organizacji szkół szczebla podstawowego i średniego oraz zapewnienia transportu uczniów ${ }^{91}$. Zarazem też warto zauważyć utrzymujący się problem braku odpowiedniej edukacji regionalnej, zwłaszcza w aspekcie historycznym. Lekcje poświęcone przeszłości małej ojczyzny realizowane są głównie z inicjatywy samych nauczycieli, w ramach projektów zewnętrznych lub jako zajęcia dodatkowe ${ }^{92}$. Podobnie działalność samorządów siłą rzeczy ogranicza się do finansowania podręczników przybliżających historię regionalną, nie mając jednak pewności, czy i jak będą one wykorzystane w edukacji dzieci i młodzieży ${ }^{93}$.

Warto zatem zastanowić się, czy miasta mogą posługiwać się tym narzędziem uprawiania polityki historycznej, $\mathrm{w}$ dodatku w ujęciu międzynarodowym. Wydaje się, że mimo sztywnych ram, w których samorządy kreują politykę edukacyjną, pewne działania w tym kierunku są możliwe. Wspomniano już o wspólnych inicjatywach realizowanych przez partnerów

89 J. Michalak, Wspótcześnie o przeszłości, czyli wplyw polityki historycznej na kształt podręczników szkolnych, „Klio” 2011, nr 16(1), s. 180.

90 Por. W. Lib, System edukacyjny Stanów Zjednoczonych - ogólna charakterystyka, „Edukacja - Technika - Informatyka” 2018, nr 2(25), s. 65-72; M. Ślusarczyk, Edukacja tematem wyborczym - polityczne uwarunkowania reform systemów oświaty, "Kultura i Edukacja” 2005, nr 3, s. 22-36.

91 P. Kubicki, J. Wiśniewski, P.Zbieranek, Samorząd a edukacja - kwestie do dyskusji, [w:] Samorząd a edukacja, red. P. Kubicki, P.Zbieranek, Instytut Badań nad Gospodarką Rynkową, Gdańsk 2011, s. 8.

92 Por. T. Stachurska-Maj, Historia reǵionalna jako przekaz wartości w edukacji historycznej, „Meritum” 2016, nr 3(42), s. 37-40.

93 Przykładem jest wydany z inicjatywy Urzędu Marszałkowskiego Województwa Warmińsko-Mazurskiego podręcznik: Dziedzictwo ziem pruskich. Dzieje i kultura Warmii i Mazur, red. I. Lewandowska, ElSet, Olsztyn 2012. 
polskich i zagranicznych, a dotyczących m.in. odkrywania wspólnego dziedzictwa. Obok zatem dwustronnych wystaw, konferencji czy wymian młodzieży publikowane są wspólne wydawnictwa przybliżające przeszłość konkretnego miasta czy regionu. Zazwyczaj ukazują się one w co najmniej dwóch wersjach językowych, a ponadto są dystrybuowane wśród odbiorców zagranicznych, w związku z czym wykazują potencjał do kształtowania pamięci zbiorowej $\mathrm{w}$ wymiarze ponadnarodowym. Istotny walor edukacyjny posiadają ponadto różnego rodzaju informatory, albumy okolicznościowe i inne publikacje wydane nakładem samorządów lub przy ich wsparciu finansowym. Co prawda ich oddziaływanie ma ograniczony charakter - zważywszy na nakład oraz dostępność - jednak dzięki obecności w bibliotekach i szkołach stanowią one jedno z podstawowych źródeł wiedzy o przeszłości danego miasta dla osób z zagranicy. Podobnie jak tradycyjny podręcznik, także wspomniane wydawnictwa przedstawiają określoną wizję historii, wpisującą się w politykę władz samorządowych. Zarazem też służą turystom oraz obcokrajowcom zainteresowanym daną miejscowością. Przykładem takiej publikacji jest wydawnictwo przygotowane przez władze wspomnianego już Gorzowa Wielkopolskiego z okazji 760-lecia nadania praw miejskich, opublikowane $\mathrm{w}$ języku polskim, niemieckim i angielskim $^{94}$. Podobne inicjatywy wydawnicze regularnie pojawiają się nakładem pozostałych samorządów.

\section{Pozostałe narzędzia dyplomacji pamięci}

Jak już to zaznaczono, miasta realizują własną politykę zagraniczną przy użyciu szerokiego instrumentarium. Takiej sytuacji sprzyja brak sprecyzowanych kompetencji samorządów oraz ich roli na arenie międzynarodowej. Podobnie ma się rzecz z ponadnarodowym aspektem polityki historycznej, która wymyka się prostym klasyfikacjom. Obok zatem wspomnianych narzędzi, takich jak wykorzystanie przestrzeni symbolicznej czy działalność instytucji pamięci, miasta sięgają również po dodatkowe możliwości. Jedną z form paradyplomacji pamięci z pewnością jest współpraca samorządów w ramach programu miast partnerskich. W zależności od zaangażowania

94 Por. Gorzów Wielkopolski, Urząd Miasta Gorzowa Wielkopolskiego, Wydział Promocji i Informacji, Gorzów Wlkp. 2017. 
poszczególnych władz relacje dwustronne mogą wykraczać poza oficjalne spotkania oraz prowadzić do realizacji wspólnych projektów. Jako przykład działalności miast partnerskich, odnoszącej się do historii, można wskazać projekt pt. „Szlakiem dziedzictwa kulturowego”, realizowany przez Przemyśl i słowackie Humenne ${ }^{95}$. Głównym jego celem jest rozwój turystyki oparty na popularyzacji dziejów obu miast. Szeroką współpracę w zakresie przybliżania historii podjęło także miasto Kostrzyn nad Odrą, które razem z niemieckimi Peitz, Seelow oraz Berlin Spandau współtworzyło projekt promocji

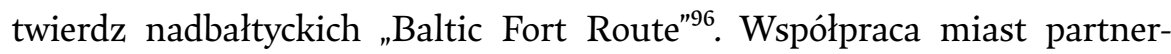
skich wykorzystywana jest ponadto do przezwyciężenia trudnej przeszłości, ustanowienia wspólnej narracji, podkreślającej pozytywne aspekty historii, a marginalizującej negatywne ${ }^{97}$. W tym duchu realizowane są m.in. wspólne działania Lwowa z jego polskimi miastami partnerskimi ${ }^{98}$.

Bezpośrednim narzędziem polityki historycznej, którym dysponują władze miejskie, są media społecznościowe. Jak wskazują badacze komunikacji politycznej, wraz z migracją polityki do cyberprzestrzeni postępuje proces jej dalszej mediatyzacji, a w konsekwencji następuje utożsamienie oficjalnej polityki miasta czy innego podmiotu z publicznymi wypowiedziami jego przywódców ${ }^{99}$. Dzięki niemal nieograniczonemu zasięgowi, uzyskiwanemu za pośrednictwem popularnych platform społecznościowych, takich jak Facebook czy Twitter, prezydenci czy burmistrzowie mogą swobodnie komunikować się nie tylko z własnymi wyborcami, ale też oddziaływać zdecydowanie szerzej. W tym celu liderzy największych miast prowadzą swoje profile również w kilku wersjach językowych, kierując je do wszystkich

95 Szlakiem dziedzictwa kulturowego. Przemyśl - Humenne, Urząd Miasta Przemyśl, Przemyśl 2011.

96 Kostrzyn nad Odrą, [dostęp: 10 III 2021], dostępny w internecie: <http://miasto. lh.pl/twinning/mapa/pl/info,493,kostrzyn_nad_odra.html\#info $>$.

97 S. A. Bollens, Urban governance at the nationalist divide. Coping with group-based claims, „Journal of Urban Affairs” 2007, vol. 29, no. 3, s. 229-253.

98 K. Nowicka, I. Sagan, D. Studzińska, Small diplomacy. Cultural cooperation as a factor alleviating societal tensions. The case of Lviv and its Polish partner cities, "Geopolitics" 2019, vol. 24, no. 3, s. 565-585.

99 Por. M. Lakomy, Demokracja 2.0. Interakcja polityczna w nowych mediach. Dyskurs politologiczny, Wydawnictwo Universitas, Kraków 2013, s. 197. 
zainteresowanych ${ }^{100}$. W przypadku Twittera rekordzistą pośród prezydentów polskich miast jest Rafał Trzaskowski, którego profil obserwuje ponad 540 tys. osób ${ }^{101}$. Niemal 18 tys. śledzi wpisy prezydenta Wrocławia Jacka Sutryka, a Jacka Jaśkowiaka - prezydenta Poznania - ok. 12,5 tys. ${ }^{102}$. Zdaniem Anny Stoppel polscy politycy dopiero uczą się wykorzystywać media społecznościowe do osiągania celów politycznych, takich jak mobilizacja czy ustanawianie agendy ${ }^{103}$. Stąd też w większości przypadków użycie portali społecznościowych jako narzędzia polityki historycznej ma głównie wymiar krajowy, nie międzynarodowy. $\mathrm{W}$ o wiele większym stopniu cyberprzestrzeń wykorzystują samorządowcy amerykańscy. Przykładowo oficjalny profil Billa de Blasio, burmistrza Nowego Jorku, obserwuje ponad 1,5 miliona osób. Co więcej, w tym gronie znajdują się nie tylko popularni celebryci i lokalni politycy, ale także szefowie rządów wielu państw świata. Pozwala mu to wykorzystywać media społecznościowe do ustanawiania pożądanej narracji, również na tematy historyczne, jak chociażby upamiętnienie ofiar zamachów z 11 września 2001 r. czy kwestie rasowych nierówności w dziejach Stanów Zjednoczonych ${ }^{104}$.

Do instrumentarium polityki historycznej skierowanej na zewnątrz można również zaliczyć pozostałe, tradycyjne narzędzia prowadzenia dyplomacji. Warto tutaj wymienić chociażby podróże zagraniczne włodarzy miast lub ich przedstawicieli, które często zyskują rangę porównywalną z wizytami szefów rządów lub głów państw. Największe miasta posiadają specjalistyczne komórki odpowiedzialne za organizację wyjazdów zagranicznych. Wspomniany już burmistrz Nowego Jorku Bill de Blasio w czasie dwóch pierwszych lat swojej kadencji odwiedził trzy kontynenty, składając oficjalne wizyty m.in. w Wielkiej Brytanii, Francji, Włoszech i Izraelu ${ }^{105}$. Obok rozmów na tematy gospodarcze spotkania te były okazją do przypomnienia

100 Por. D. Giacomini, A. Simonetto, How mayors perceive the influence of social media on the policy cycle, „Public Organization Review” 2020, nr 20, s. 735-752.

101 Twitter, dane z 12 VIII $2021 \mathrm{r}$.

102 Twitter, dane z 12 VIII $2021 \mathrm{r}$.

103 A. Stoppel, Nowe media w polityce, FNCE, Poznań 2020, s. 349.

104 D. Rubinstein, J. C. Mays, De Blasio denounced after police forcefully clash with protesters, „The New York Times”, 5 czerwca 2020, s. A16.

105 M. G. Grynbaum, Bill de Blasio to travel to Israel next week, a tradition for New York mayors, „The New York Times”, 9 X 2015, s. A29. 
historii amerykańskiej metropolii. Także mniejsze ośrodki powołują różnego rodzaju biura czy referaty współpracy zagranicznej, których rolą jest m.in. obsługa zagranicznych interesantów i delegacji. Chociaż koncentrują się one na kwestiach gospodarczych, to coraz częściej zdają sobie sprawę ze znaczenia polityki historycznej dla budowy turystycznego potencjału miasta. Taki cel miała m.in. wizyta zastępcy prezydenta Gdańska w Paryżu w związku ze złożeniem wniosku w UNESCO o wpisanie dawnej stoczni gdańskiej na Listę Światowego Dziedzictwa w 2020 r. Warto wspomnieć, że tematyka historyczna podejmowana podczas zagranicznych wizyt włodarzy miast może prowadzić do sporów z władzami centralnymi. Taka sytuacja zaistniała w 2018 r., kiedy podczas Konferencji Prezydentów Miast w Izraelu prezydent Poznania Jacek Jaśkowiak otwarcie skrytykował politykę historyczną polskiego rządu ${ }^{106}$. Kreowanie odpowiedniej narracji o przeszłości odbywa się również poprzez udział miast w organizacjach międzynarodowych. Szczególnie aktywny na tym polu jest Kraków, który w czerwcu 2019 r. gościł kilkuset przedstawicieli miast podczas 15. Kongresu Organizacji Miast Światowego Dziedzictwa.

\section{Podsumowanie}

Miasta zyskują coraz większą podmiotowość w stosunkach międzynarodowych. Posługując się instrumentarium, które do niedawna było w dyspozycji wyłącznie władz państwowych, realizują własne cele wewnętrzne i zewnętrzne ${ }^{107}$. Podobnie jak w przypadku relacji międzyrządowych, także w polityce zagranicznej samorządów daje się coraz wyraźniej zauważyć oddziaływanie historii. Polityka pamięci, nakierowana na lansowanie określonej wizji przeszłości, staje się jednym z elementów paradyplomacji samorządów. Odwołania do historii wspierają nadrzędny cel polityki zagranicznej miast, jakim jest podniesienie własnego potencjału gospodarczego

106 Prezydent Poznania pojechał do Izraela i krytykuje rząd PiS, „Rzeczpospolita” [online], 15 II 2018 [dostęp: 23 II 2021], dostępny w internecie: <https:/www.rp.pl/ Konflikt-Polska-Izrael/180219553-Prezydent-Poznania-pojechal-do-Izraela-ikrytykuje-rzad-PiS.html>.

107 M. Lackowska, Miejska polityka „zagraniczna”. Koncepcja przeskalowania w doświadczeniach polskich miast, Wydawnictwo Uniwersytetu Warszawskiego, Warszawa 2014, s. 29. 
i politycznego. Samorządy sięgają przy tym po tradycyjne środki polityki historycznej, takie jak zagospodarowanie przestrzeni symbolicznej, wspieranie działalności instytucji pamięci czy wpływ na system edukacji. Niemniej warto zauważyć, że w wielu przypadkach inicjatywa należy do rządów centralnych, miasta zaś stanowią jedynie przestrzeń do realizacji państwowej polityki historycznej. Więcej autonomii władze lokalne posiadają w pozostałych formach oddziaływania na społeczność międzynarodową, jak np. współpraca w ramach miast partnerskich, wizyty zagraniczne lub obecność przedstawicieli władz miejskich na portalach społecznościowych.

Współczesna aktywność międzynarodowa liderów najpotężniejszych miast, takich jak Nowy Jork, Berlin, Londyn czy Paryż, dowodzi ich skuteczności, także w przypadku prowadzonej przez nich polityki historycznej. Lansowana przez nich narracja o konkretnych wydarzeniach i postaciach z przeszłości trafia nie tylko do mieszkańców tych ośrodków, ale staje się częścią pamięci zbiorowej społeczności międzynarodowej. Upamiętnienie zamachów terrorystycznych z 11 września 2001 r. na wieże World Trade Center w Nowym Jorku uczyniło z tej tragedii element globalnego kanonu pamięci, podobnie jak uroczystości poświęcone pomordowanym Żydom w Berlinie kształtują wyobrażenia o Holokauście znacznie szerzej niż jedynie wśród mieszkańców niemieckiej stolicy. Ponadto mniejsze ośrodki sięgają po instrumentarium polityki historycznej, aby w ten sposób budować własne soft power. Dotyczy to szczególnie miast pogranicza, które należy wręcz uznać za prekursorów samorządowej dyplomacji pamięci. Biorąc zatem pod uwagę dotychczasowe pozytywne doświadczenia w stosowaniu instrumentarium polityki historycznej w relacjach międzyrządowych, można spodziewać się dalszej intensyfikacji działań nakierowanych na kształtowanie zbiorowych wyobrażeń o przeszłości również w polityce zagranicznej miast.

\section{Bibliografia}

Aguirre I., Making sense of paradiplomacy. An intertextual enquiry about a concept in search of a definition, „Regional and Federal Studies” 1999, vol. 9, no. 1.

Assmann A., Transformations between history and memory, "Social Research” 2008, vol. 75 .

Boyer M. Ch., The city of collective memory. Its historical imagery and architectural entertainments, MIT Press, Cambridge 1994.

Brzeziecki A., Markowski K., Wszystkie nasze spory o pamięć, „Znak” 2020, nr 5. 
Curtis S., Acuto M., The foreign policy of cities, „RUSI Journal” 2018, vol. 163, no. 6. Curtis S., The meaning of global cities. Rethinking the relationship between cities, states, and international order, [w:] The power of cities in international relations, red. S. Curtis, Routledge, New York 2014.

Curyło B., Paradyplomacja. Rozważania na temat wybranych determinant aktywności międzynarodowej regionów, [w:] Artificem commendat opus. Region-pamięć-polityka. Studia i materiały ofiarowane profesor Danucie Kisielewicz, red. E. Ganowicz, Wydawnictwo Uniwersytetu Opolskiego, Opole 2018.

Faliński S., Wspótpraca międzynarodowa miasta na prawach powiatu. Przykład Płocka, „Studia z Polityki Publicznej” 2019, nr 3(23).

Hahn H.H., Pamięć zbiorowa - przedmiot polityki historycznej?, [w:] Narodowe $i$ europejskie aspekty polityki historycznej, red. B. Korzeniewski, Wydawnictwo Instytutu Zachodniego, Poznań 2008.

Held D., McGrew A., "The end of the old order?". Globalization and the prospects for world order, „Review of International Studies” 2001, vol. 24, no. 3.

Kącka K., Polityka historyczna. Kreatorzy, narzędzia, mechanizmy - przykład Polski, [w:] Narracje pamięci. Między polityka a historia, red. K. Kącka, J. PiechowiakLamparska, A. Ratke-Majewska, Wydawnictwo Uniwersytetu Mikołaja Kopernika, Toruń 2015.

Kamiński T., Paradiplomacy - Discourse analysis and research conceptualization, [w:] Paradiplomacy in Asia. Case studies of China, India and Russia, red. M. Pietrasiak, G. Bywalec, T. Kamiński, D. Mierzejewski, M. Słowikowski, Wydawnictwo Uniwersytetu Łódzkiego, Łódź 2018.

Kurz I., Przepisywanie pamięci. Przypadek Muzeum Powstania Warszawskiego, „Kultura Współczesna” 2007, nr 3(53).

Kuznetsov A. S., Theory and practice of paradiplomacy. Subnational governments in international affairs, Routledge, London and New York 2015.

Lecours A., Political issues of paradiplomacy. Lessons from the developed world, „International Negotiation” 2002, vol. 7, no. 1.

Modzelewski W.T., Dyplomacja bez dyplomatów. Polsko-chorwackie partnerstwa regionalne, "Studia Regionalne i Lokalne” 2020, nr 4(82).

Neves M. S., Paradiplomacy, Knowledge regions and the consolidation of "soft power", „Janus.net. E-journal of International Relations” 2010, vol. 1, no. 1.

Nijakowski L. M., Polska polityka pamięci. Esej socjologiczny, Wydawnictwa Akademickie i Profesjonalne, Warszawa 2008.

Nye J.S. jr., Soft power. Jak osiagnąć sukces $w$ polityce światowej, Wydawnictwa Akademickie i Profesjonalne, Warszawa 2007.

Posłuszny Ł., Miejsca pamięci. Przestrzeń - pamiętanie - zapominanie $w$ kontekście Pomnika Pomordowanych Żydów Europy, [w:] Miejsca pamięci w świadomości współczesnego człowieka, red. K. Zieliński, J. Janikowska, Wydawnictwo Akapit, Toruń 2015.

Sodaro A., Prosthetic trauma and politics in the National September 11 Memorial Museum, „Memory Studies” 2019, vol. 12, no. 2. 
Szpociński A., Wspótczesna kultura historyczna i jej przemiany, Wydawnictwo Naukowe Scholar, Warszawa 2021

Wasilewski K., Między Nową Marchią a Wołyniem. O lokalnej polityce historycznej i pamięci zbiorowej mieszkańców Gorzowa Wielkopolskiego, „Przegląd Zachodni” 2019, nr 3.

Wasilewski K., Zjednoczenie Niemiec a transkulturacja polityki historycznej i pamięci zbiorowej mieszkańców pogranicza polsko-niemieckiego na przykładzie Ziemi Lubuskiej, „Rocznik Polsko-Niemiecki” 2020, nr 28.

Wolff S., Paradiplomacy. Scope, opportunities and challenges, „Bologna Center Journal of International Affairs" 2007, vol. 10. 